\title{
Micropropagation of Inula germanica L. from the Seedlings Explants
}

\author{
Alina TREJGELL*, Monika KAMIŃSKA, Karolina LISOWSKA, \\ Andrzej TRETYN
}

\begin{abstract}
Nicolaus Copernicus University, Faculty of Biology and Environmental Protection, Chair of Plant Physiology and Biotechnology, Lwowska 1, Torun, Poland; trejgell@umk.pl (*orrespondingauthor);mokkam@doktorant.umk.pl;250651@stud.umk.pl;prat@umk.pl
\end{abstract}

\begin{abstract}
This is the first communication of micropropagation system for Inula germanica using seedling explants germinated in vitro. The development of this system gives the possibility of future reintroduction of I. germanica providing a way to stabilize or re-establish its population. Shoot tips and fragments of cotyledons, hypocotyls and roots were isolated from ten-day-old seedlings. Explants were put on MS medium containing $1.0 \mathrm{mg} \mathrm{l}^{-1}$ benzylaminopurine and $0.1 \mathrm{mg} \mathrm{l}^{-1}$ naphthaleneacetic acid and cultured under continuous white fluorescent light $\left(45 \mu \mathrm{mol} \mathrm{m}^{-2} \mathrm{~s}^{-1}\right)$ at $26 \pm 1{ }^{\circ} \mathrm{C}$. The highest percentage of shoot organogenesis (83.3\%) was recorded for hypocotyl, while the highest average number of shoots per explant (12.0) was recorded for shoot tips. In subsequent subcultures, multiplication rate decreased to 3.0-4.9 shoots per explant. Less than 19\% shoots were able to root on the solid medium without auxins. The highest rooting efficiency $(69.3 \%)$ was recorded for solid medium supplemented with indolebutyric acid, but growth of roots was inhibited. The percentage of rooted shoots (62.2\%) and number of roots per shoot (2.4 per shoot) into the liquid medium were comparable to medium with $0.1 \mathrm{mg} \cdot \mathrm{l}^{-1}$ indolebutyric acid. showing a positive impact on the process of acclimatization. The regenerated plants were able to flowering in the first year after acclimatization. Developed micropropagation system for I. germanica is efficient and can be a useful tool for the active protection of this species.
\end{abstract}

Keywords: Asteraceae, endangered species, solid and liquid medium, shoot multiplication, rooting in vitro

\section{Introduction}

Inula germanica is extremely endangered species and listed as critically endangered (CR) in Polish red lists (Mirek and Zarzycki, 2006). I. germanica has a wide natural distribution from the southern Ural Mountains through the southern part of Russia, the Caucasus, in southern and central Ukraine, the Balkan Peninsula, the Pannonian plain to eastern Austria and central Germany (Rutkowski and Paszek, 2000). In Poland, there is only one single site Bielinek on the Oder River (Kaźmierczakowa et al., 2014). However, natural succession occurs in this area (growth of shrubs and trees) and limits the size of the population of $I$. germanica, which is manifested by small flowering shoots, moreover, in some years, individuals do not bloom. Therefore, developing an effective system of regeneration would be a useful tool to active protection of this species. The technique of in vitro culture supports conservation of plant genetic resources without depleting their natural position, because it requires small fragments of plants or only a few seeds to initiate the regeneration process (Rybczyński and Mikuła, 2006). Additionally, I. germanica produces germanins (germacranolides, sesquiterpene lactones), that show a wide spectrum of biological activity, including anti-cancer properties (Liszewska, 2011) and plants micropropagated using in vitro techniques could be the source of these substances.

There are many research reports upon the tissue culture of Asteraceae. Most of these studies focused on obtaining an efficient system for in vitro propagation of crop or medical importance plants, e.g. Echinacea purpurea (Zobayed and Saxena, 2003) or Carthamus tinctorius (Kumar and Kumari, 2011) via somatic embryogenesis, while regeneration by organogenesis has been developed for Heliantus annus (Ozyigit et al., 2007), Launaea sarmentosa (Mahesh et al., 2012), and many others (Amin et al., 2013). Moreover, efficient and rapid clonal regeneration method has been shown to be a great tool in the protection of rare and threatened species of the Asteraceae family e.g. Centaurea ultreiae (Mallón et al., 2011), Carlina onopordipholia (Trejgell et al., 2011), Arnica montana (Surmacz-Magdziak and Sugier, 2012), or Taraxacum pieninicum (Trejgell et al., 2013) and others (Amin et al., 2013).

The species of Inula genus, I. viscose (Romano, 1997), I. royleana (Stojakowska and Malarz, 2004), I. verbascifolia 
(Perica et al., 2008), I. japonica (Bian et al., 2008) and $I$. racemosa (Kaur et al., 2010) have been successfully micropropagated. However, previous papers on I. germanica only describe the morphological, phytoecological and ecological studies (Rutkowski and Paszek, 2000). To our knowledge this is the first protocol for in vitro propagation of this species via shoot multiplication. Developing an effective system of regeneration would be a useful tool for conservation of this species and others members of the Asteraceae family.

\section{Materials and Methods}

\section{Plantmaterial}

The seeds were picked from the collection of the Botanical Garden of UMCS in Lublin (Poland). They were sterilized with $70 \%(\mathrm{v} / \mathrm{v})$ ethanol for $30 \mathrm{~s}$ and then $20 \%$ $(\mathrm{v} / \mathrm{v})$ commercial bleach with sodium hypochloride (Domestos ${ }^{\circ}$ ) for $20 \mathrm{~min}$. Then they were washed 4 times using sterile distilled water and transferred onto Petri dishes $(6 \mathrm{~cm}$ in diameter) containing $10 \mathrm{ml}$ of MS medium including vitamins (Duchefa) (Murashige and Skoog, 1962) supplemented with $3.0 \%$ sucrose, $1 \mathrm{mg} \mathrm{l}^{-1}$ gibberellic acid (GA3) and gelling with $0.7 \%$ agar (Sigma-Aldrich, Germany). The $\mathrm{pH}$ was adjusted to 5.8 and the medium was autoclaved for $20 \mathrm{~min}$ at $121{ }^{\circ} \mathrm{C}$. The seeds were cultivated under continuous white fluorescent light (45 $\left.\mu \mathrm{molm} \mathrm{m}^{-2} \mathrm{~s}^{-1}\right)$ at $26 \pm 1^{\circ} \mathrm{C}$ in growth chambers.

\section{Establishment of the culture and multiplication}

Shoot tips cut under the cotyledonary node $(2-3 \mathrm{~mm}$ in length), fragments of cotyledons $(2-3 \mathrm{~mm}$ in length), hypocotyls (1 $\mathrm{mm}$ in length, cut out under the node), and roots ( $5 \mathrm{~mm}$ in length) were isolated from a ten-day-old seedlings and were used as initial explants. The explants (4 per flask) were cultivated in $100 \mathrm{ml}$ Erlenmeyer flasks loaded with $30 \mathrm{ml}$ of MS medium containing $1.0 \mathrm{mg} \mathrm{l}^{-1}$ benzylaminopurine (BAP) and $0.1 \mathrm{mg}^{-1}$ naphthaleneacetic acid (NAA), $3.0 \%$ sucrose, solidified with $0.7 \%$ agar and $\mathrm{pH}$ adjusted to 5.8 before autoclaving. They were maintained for 4 weeks under conditions described above. In our earlier studies on the regeneration of species of the Asteraceae family, the medium composition and the environmental parameters were optimized (Trejgell and Tretyn, 2010). The shoots were subcultured 4 times at 4 weeks intervals. After this period, the multiplication rate and percentage of explants producing shoot were analyzed.

\section{Rooting and acclimatization}

The shoots $\left(1 \mathrm{~cm}\right.$ and longer) obtained in the $3^{\text {th }}$ subculture were excised and rooted into $50 \mathrm{ml}$ tubes containing $10 \mathrm{ml}$ solid or liquid MS medium solidified with $0.7 \%$ agar and supplemented with $0.1 \mathrm{mg} \cdot \mathrm{l}^{-1}$ indole-3butyric acid (IBA). Solid medium without IBA was used as a control. Furthermore, the liquid MS medium without auxins was tested, adding perlite $(1.5 \mathrm{~g})$ in order to maintain the shoot in a vertical position. The shoots were maintained for 4 weeks under conditions described above. The plantlets obtained after 4 weeks of culture were removed from the in vitro cultures, and then percentage of rooting, number of roots and length of roots were analyzed. The plantlets from solid medium were gently washed in sterile water and transferred into plastic pots filled with a sterile mixture of vermiculite and sand (1:1). The plantlets from liquid medium were directly transferred to pots filled with the same substrate. After 4 weeks of hardening, the microcuttings were transferred to pots containing soil and acclimatized for the next 4 weeks in a greenhouse. After 8 weeks of plantlets acclimatization, their survival percentage was recorded and they were transferred to the field conditions.

\section{Statistical analysis}

During multiplication stage, each treatment consisted of 12 explants (for initial material) and at least 16 shoots (for the following subcultures), and during rooting stage, 24 shoots for each treatments, were used. All experiments were carried out in two replicates. Results were statistically analyzed by means of ANOVA and the mean values were evaluated by Kruskal-Wallis test for varied numbers of collections (multiplication stage) or by Tukey test for equal numbers of collections (rooting stage) at $p<0.05$.

\section{Results and Discussion}

\section{Shoot multiplication}

In the present studies on I. germanica, morphogenetic responses of seedlings explants on MS medium containing 1

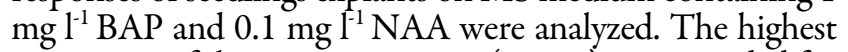
percentage of shoot organogenesis (83.3\%) was recorded for hypocotyl fragments with average of $6.3 \pm 1.1$ adventitious shoots per explant (Table 1). The shoot organogenesis frequency for shoot tips and cotyledons was $66.7 \%$ and $50 \%$, respectively. Whereas the average number of shoots per explant was $12.0 \pm 1.2$ for shoot tips and $10.1 \pm 0.8$ for cotyledons (Fig. 1A and B) and the differences were statistically significant as compared to the results obtained for the hypocotyl (Table 1). The root explants were not able to produce shoots by organogenesis. Similar results were recorded for Carlina acaulis and C. onopordifolia (Trejgell et al., 2009; Trejgell and Tretyn, 2011). The difference in shoot formation between different types of explants in response to BAP could be related to the levels of endogenous cytokinins (Yucesan et al., 2007) or to differences in tissue sensitivity to plant growth regulators (Lisowska and Wysokinska, 2000). In previous studies on different species of the Asteracae family, e.g. Artemisia, Carlina, Echinacea and Saussurea species and also Stevia rebaudiana, Atractylodes lancea or Silphium perfoliatum, it was found that $\mathrm{BAP}$ was the most effective growth regulator for in vitro proliferation (Amin et al., 2013). BAP was also necessary for the $I$. racemosa shoots regeneration and the highest rate of shoot multiplication was obtained on a medium fortified with $1 \mathrm{mg} \mathrm{l}^{-1}$ BAP (Kaur et al., 2010). Other authors observed that BAP at the same concentration in combination with NAA was the most effective for Acmella calva (Amudha and Shanthi, 2011), Centaurea arifolia (Yüzbaşığlu et al., 2012), Eclipta alba (Sharma et al., 2013), and Carthamus tinctorius (Ghasempour et al., 2014). In addition, in our previous study, $1 \mathrm{mg} \mathrm{l}^{-1} \mathrm{BAP}$ and $0.1 \mathrm{mg} \mathrm{l}^{-1} \mathrm{NAA}$ were the most efficient concentration of those growth regulators for multiplication of shoots for Carlina acaulis, Leontopodium 
54

Table 1. Effects of the source of explants and the number of subcultures on percentage of explants producing shoots, and proliferation rates developing on explants of Inula germanica isolated from seedlings after 4 weeks of culture on MS supplemented with 1 mg $1^{-1} \mathrm{BAP}$ and $0.1 \mathrm{mg} \mathrm{l^{-1 }} \mathrm{NAA}$

\begin{tabular}{|c|c|c|c|c|c|c|c|c|}
\hline \multirow[b]{2}{*}{$\begin{array}{l}\text { Type of } \\
\text { explants }\end{array}$} & \multicolumn{2}{|c|}{ Initial culture } & \multicolumn{2}{|c|}{ 1st subculture } & \multicolumn{2}{|c|}{ 2nd subculture } & \multicolumn{2}{|c|}{ 3rd subculture } \\
\hline & $\begin{array}{c}\% \text { of explants } \\
\text { producing } \\
\text { shoots }\end{array}$ & $\begin{array}{c}\text { Number of } \\
\text { shoots } \\
\text { /explant }\end{array}$ & $\begin{array}{c}\% \text { of explants } \\
\text { producing } \\
\text { shoots }\end{array}$ & $\begin{array}{c}\text { Number of } \\
\text { shoots } \\
\text { /explant }\end{array}$ & $\begin{array}{c}\text { \% of explants } \\
\text { producing } \\
\text { shoots }\end{array}$ & $\begin{array}{c}\text { Number of } \\
\text { shoots } \\
\text { /explant }\end{array}$ & $\begin{array}{c}\text { \% of explants } \\
\text { producing } \\
\text { shoots }\end{array}$ & $\begin{array}{c}\text { Number of } \\
\text { shoots } \\
\text { /explant }\end{array}$ \\
\hline Shoot tip & $66.7 \pm 2.7$ & $12.0 \pm 1.2 \mathrm{a} \mathrm{A}$ & $92.3 \pm 4.3$ & $4.1 \pm 0.7$ a B & $83.3 \pm 3.3$ & $3.4 \pm 0.7$ a B & $67.9 \pm 5.0$ & $4.9 \pm 0.9$ a B \\
\hline Hypocotyl & $83.3 \pm 6.7$ & $6.2 \pm 1.1 \mathrm{~b} \mathrm{~A}$ & $84.6 \pm 11.4$ & $2.2 \pm 0.3 \mathrm{~b} \mathrm{~B}$ & $96.0 \pm 3.2$ & $3.7 \pm 0.5$ a C & $100.0 \pm 0.0$ & $3.0 \pm 0.5$ a BC \\
\hline Cotyledon & $50.0 \pm 10.0$ & $10.1 \pm 0.8$ a A & $100.0 \pm 0.0$ & $6.6 \pm 0.9$ a B & $98.9 \pm 0.2$ & $4.2 \pm 0.4 \mathrm{a} \mathrm{C}$ & $100.0 \pm 0.0$ & $4.2 \pm 0.8$ a C \\
\hline
\end{tabular}

${ }^{*}$ Means \pm standard error, means with small different letter within columns and capital letters within the rows indicate significant differences by ANOVA followed by Kruskal-Wallis test at $\mathrm{p}<0.05$
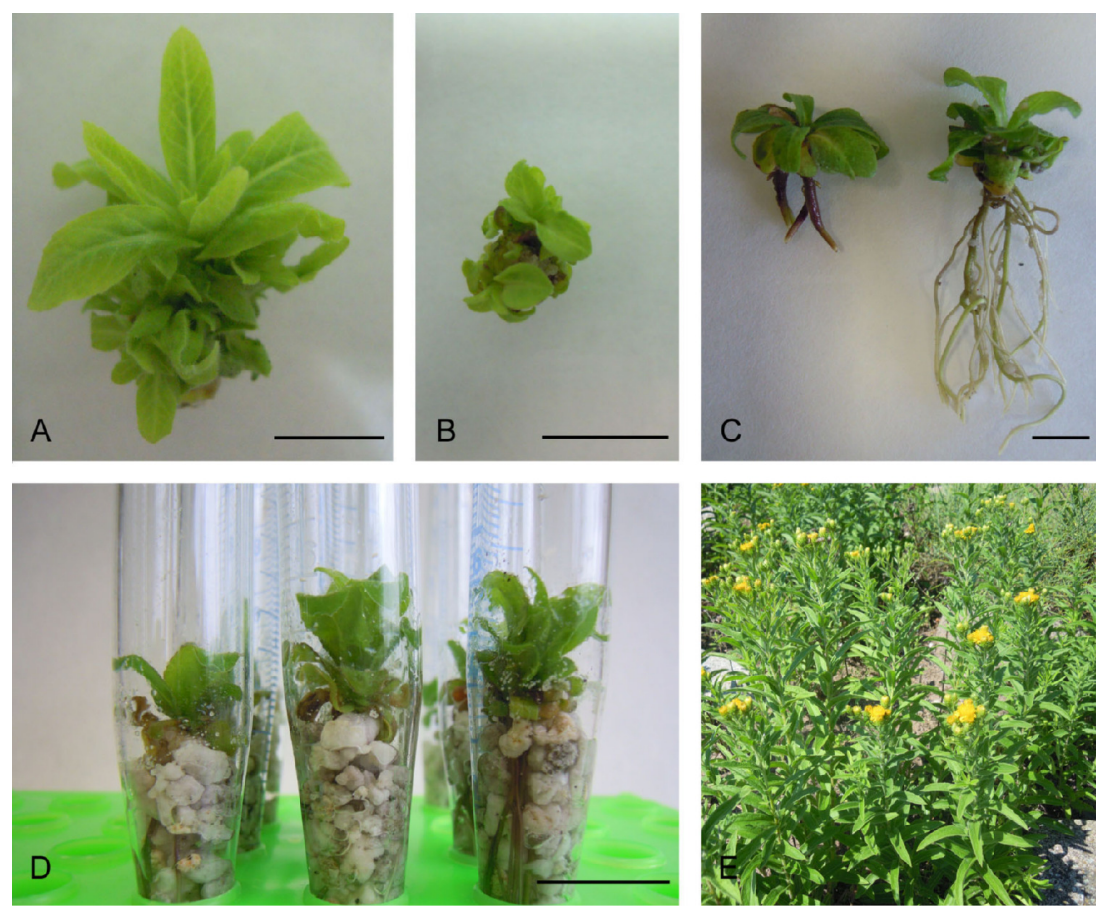

Fig. 1. Micropropagation of Inula germanica: (A) multiple shoots from shoot tip and (B) from fragment of cotyledon after 4 weeks of culture on MS supplemented with $1 \mathrm{mg} \mathrm{l}^{-1} \mathrm{BAP}$ and $0.1 \mathrm{mg} \mathrm{l}^{-1} \mathrm{NAA},(\mathrm{C})$ comparison of root development on solid medium (left) and in liquid medium (right), (D) rooted shoots into MS liquid medium with perlite, (E) regenerated and flowered plant in the first year after acclimatization. Bar $=10 \mathrm{~mm}$

alpinum, Senecio macrophyllus and Cirsum pannonicum (Trejgell and Tretyn, 2010).

The shoots of $I$. germanica obtained on proliferation medium after 4 weeks of culture were subcultured on the same medium. In the $1^{\text {st }}$ passage, proliferation rate decreased independent of the origin of plant material and the differences were statistically significant. The average number of shoots per explant was $4.1 \pm 0.7$ and $6.6 \pm 0.9$ for shoots obtained from the shoot tips and cotyledons, respectively, whereas the multiplication rate for shoots obtained from hypocotyls was significantly lower $(2.2 \pm$ 0.3 ). In subsequent passages, the proliferation rate remained stable for shoots obtained from the shoot tips and amounted to 3.4-4.9 shoots per explant, while for those from the hypocotyl fragments it was 3.0-3.7 shoots per explant and from cotyledons 4.2 shoots per explant. The differences in multiplication rates between materials of different origins in $2^{\text {nd }}$ and $3^{\text {rd }}$ passages as well as between passages were not statistically significant (Table 1). The obtained shoots, independent of the source of initial explants developed normally without hyperhydratises symptoms. In previous reports on the regeneration of
Launaea sarmentosa, Mahesh et al., (2012) also observed healthy shoots of good conditions on a high BAP concentration combined with a low NAA,

Rhizogenesis was not observed in any type of explants used for regeneration of $I$. germanica in both the initial material and subsequent subcultures. BAP is known as a very effective growth regulator for shoot multiplication among members of Asteraceae family. However, many reports describe the inhibitory effect of cytokinins on lateral and adventitious roots formation (De Klerk and Ter Brugge, 1992; Laplaze et al., 2007).

\section{Rooting and acclimatization}

The obtained shoots were rooted on solid MS medium without growth regulator or with $0.1 \mathrm{mg}^{-1} \mathrm{l}^{-1} \mathrm{IBA}$ (Fig. 2). The shoots were able to root on solid medium without auxin, but less than $19 \%$ of shoots rooted on this medium (Fig. 2A). Shoots have been rooted without auxin in many Asteraceae species. High rooting response was achieved for species such as Echinacea purpurea (Korach et al., 2002), Cirsium pannonicum (Trejgell et al., 2012), Arnica montana (Surmacz-Magdziak and Sugier, 2012), Artemisia 
amygdalina (Rasool et al., 2013), and Taraxacum pieninicum (Trejgell et al., 2013). Addition of IBA to medium significantly increased the percentage of rooted shoots of I. germanica (Fig. 2A), but had no effect on the number of roots (Fig. 2B). The average number of roots per shoot was $2.2 \pm 0.4$ and $1.6 \pm 0.2$ on medium without and with IBA, respectively. Jabeen et al. (2007) reported that the presence of auxin was necessary for roots induction on $I$. racemosa shoots and IBA was the most effective for this species. Stojakowska and Malarz (2004) used $0.02 \mathrm{mg} \mathrm{l}^{-1}$ IBA, which accelerated the rooting process, but had no effect on percentage of I. royleana rooted shoots. Moreover, the shoots of $I$. verbascifolia were rooted on MS medium supplied with $0.2 \mathrm{mg} \mathrm{l}^{-1}$ IBA (Thiem et al., 2003). The effective role of IBA in in vitro root induction has been described not only for the species of the genus Inula but also for other species, including Asteraceae, e.g. Artemisia absinthium (Shekhawat and Manokari, 2015), Centaurea arifolia (Yüzbaşığlu et al., 2012), or Carlina onopordifolia (Trejgell and Tretyn, 2010). However, in the case of many species, negative correlation between the root number and their length has been observed. Growth of roots of $I$. germanica on medium supplemented with $0.1 \mathrm{mg} \mathrm{l}^{-1} \mathrm{IBA}$ was inhibited as compared to roots on medium without IBA, and root lengths were $9.9 \pm 1.4$ and $18.2 \pm 3.1 \mathrm{~mm}$, respectively, and the differences were statistically significant (Fig. 2C).

The rooting of shoots into liquid medium was comparable to solid medium with IBA. The effectiveness of rooted shoots was $62.2 \%$ and number of roots per shoot was $2.4 \pm 0.2$ (Fig. 1D, Fig. 3A and B). The average length of roots was nearly $54 \mathrm{~mm}$, and they were 3 -fold longer than in solid medium, the difference was statistically significant (Fig. 3C). Moreover, they were 5-fold longer than roots obtained on solid medium with IBA (Fig. 1C). The liquid medium for the in vitro rooting was used with success for Rosa sp, Iresine sp, Rubus sp, and Ribes nigrum (Clapa and Fira, 2008). Also a positive effect of using medium with perlite during in vitro rooting on the increase of the length and weight was obtained for the Chrysanthemum root system (Tymoszuk et al., 2009). Suthar et al. (2011) observed that in the medium without agar, rooting of shoots of Boswellia serrata was more effective, not only for a greater shoot rooting percentage,, but also for the number and the roots length. Rooting percentage and root growth of Musa sapientum were also superior in the liquid medium as compared to solid medium (Akbar and Roy, 2006), while in the case of Spilanthes acmella, induction of roots was carried out on a solid medium supplemented with IBA, and then microcuttings were transferred to Magenta containing coir fiber pith irrigated with liquid MS for better growth of roots. This clearly shows that liquid medium increased the root growth. This is possibly due to the easier uptake of components from the medium. In addition, the presence of perlite in the medium might increase the content of air, which could have a significant impact on the growth of roots.

The regenerated plants with well-developed roots were transferred to ex vitro conditions. Percentage of survival was approximately $87 \%$ for plantlets rooted in solid medium and $100 \%$ for plantlets from liquid medium. These plants were able to flower in first years after acclimatization (Fig. $1 \mathrm{E})$. The probable reason of higher rate of plantlets survival, which were rooted in liquid medium, is due to a higher root length, the presence of larger number of lateral roots, better formed root hairs, and vascular bundles (Tymoszuk et al., 2009). Similar effect was reported for Artemissia absinthium, when shoots were rooted ex vitro in mixture of perlite, peat and vermiculite moistened with aqueous MS basal salt solution (Shekhawat and Manokari, 2015).

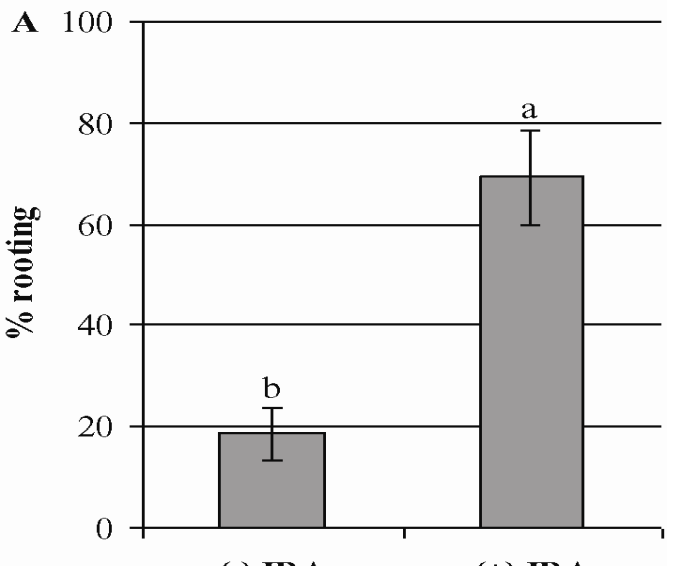

$(-)$ IBA

(+) IBA

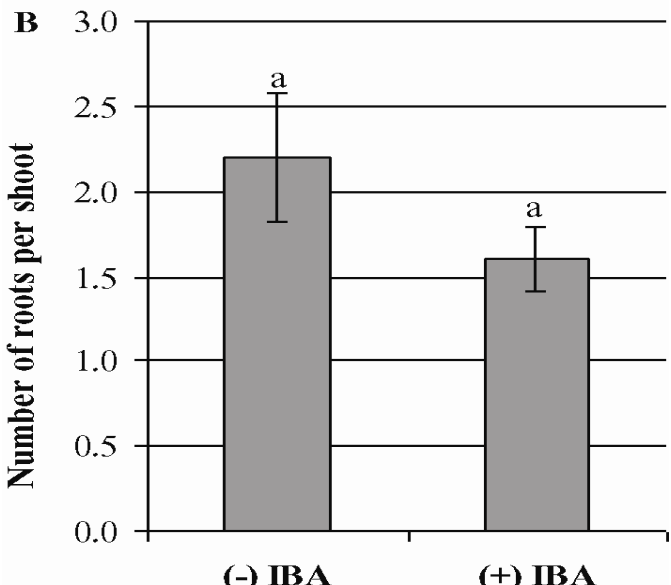

(-) IBA

(+) IBA

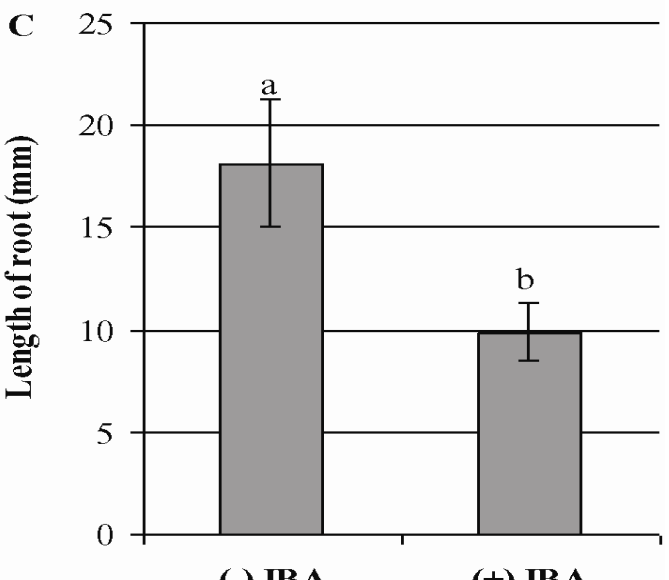

(-) IBA

(+) IBA

Fig. 2. The effect of $0.1 \mathrm{mg} \mathrm{l}^{-1} \mathrm{IBA}$ into solid MS medium on rooting of $I$. germanica shoots after 4 week of culture 
56
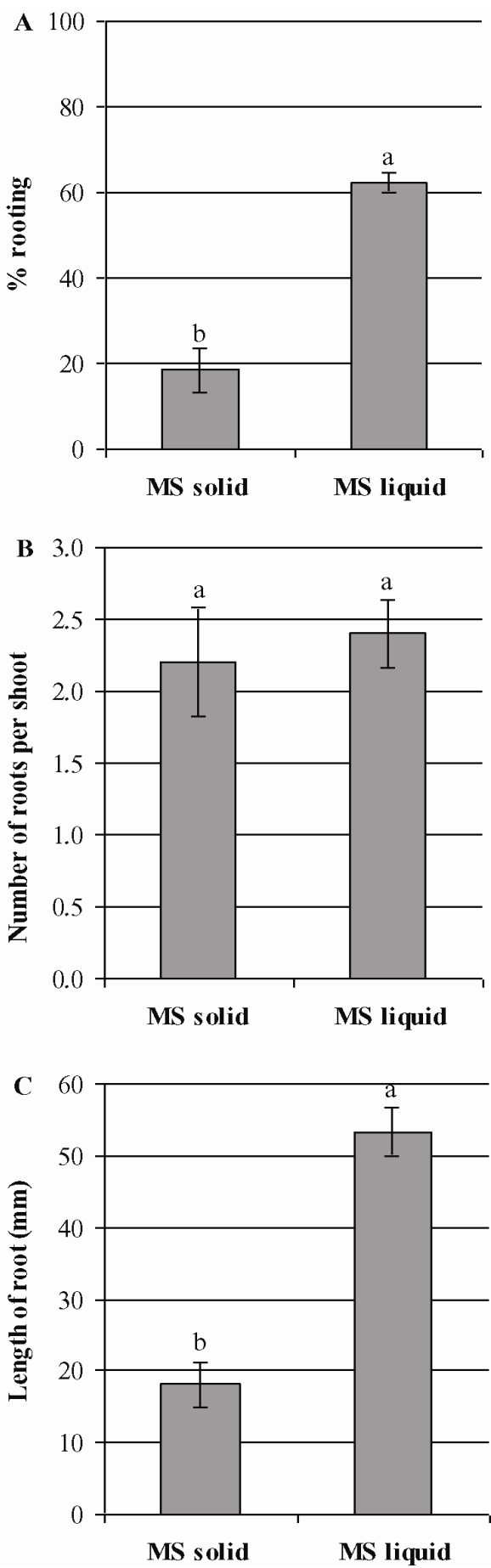

Fig. 3. The effect of liquid MS medium on rooting of $I$. germanica shoots after 4 week of culture

\section{Conclusions}

Developed micropropagation system for I. germanica can be a useful tool for the active protection of this species. It requires small amounts of initial material, which will not significantly affect the depletion of the natural environment. After induction of shoots all types of explants, multiplication of shoots on medium with $1.0 \mathrm{mg} \mathrm{l}^{-1} \mathrm{BAP}$ and $0.1 \mathrm{mg} \mathrm{l}^{-1} \mathrm{NAA}$ (during 3 subcultures) and rooting them in liquid MS medium without growth regulators, it is possible to obtain 440 plantlets per 10 seeds used to establish in vitro culture.

\section{Acknowledgements}

This Project was supported by funds provided by Nicolaus Copernicus University (Torun, Poland) for the research program of the Chair of Plant Physiology and Biotechnology.

\section{References}

Akbar MA, Roy SK (2006). Effects of liquid medium on rooting and acclimation of regenerated microshoots of banana (Musa sapientum L.) cv.Sagar. Plant Tissue Culture and Biotechnology 16(1):11-18.

Amin S, Kaloo ZA, Singh S, Altaf T (2013). Micropropagation of medicinally important species of family Asteraceae - a review. Int. International Journal of RecentScientific Research 4(8):1296-1303.

Amudha P, Shanthi P (2011). Indirect organogenesis and in vitro layering of Acmella calva (DC.) RK. Jansen. from various explants. Journal of Agricultural Technology7(3):637-648.

Bian YM, Li S, Liu MY,Li TS, Jiang CY (2008). The study of tissue culture and establishment of asexual system of Inula japonica. Journal of Agriculture and Technology 567:239.

Clapa D, Fira A (2008). The use of perlite as support in liquid media for the in vitro rooting of some horticultural species. Bulletin of the University of Agricultural Sciences and Veterinary Medicine Cluj-Napoca Agriculture 65(1):460.

De Klerk GJ, Ter Brugge J (1992). Factors affecting adventitious root formation in microcuttings of Malus. Agronomie 12(10):747-755.

Ghasempour H, Soheilikhah Z, Zebarjadi AR, Ghasempour S, Karimi N (2014). In vitro micro propagation, callus induction and shoot regeneration in safflower L. cv. Lesaf. Iranian Journal of Plant Physiology 4(2):999-1004.

Jabeen N, Shawl AS, Dar GH, Jan A, Sultan P (2007). Micropropagation of Inula racemosa Hook.f. A valuable medicinal plant. International Journal of Botany 3(3):296-301.

Kaur R, Kashyap A, Majeed S, Chauhan NS, Bhardwaj SB (2010). In vitro propagation and conservation of Inula racemosa Hook. F. an endangered medicinal plant of temperate origin. Journal of Advanced Laboratory Research in Biology 1(1):67-70.

Kaźmierczakowa R, Zarzycki K, Mirek Z (2014). Polska Czerwona Ksiega Roślin. Instytut Ochrony Przyrody PAN, Kraków pp 515-516.

Korach A, Juliani HR, Kapteyn J, Simon JE (2002). In vitro regeneration of Echinacea purpurea from leaf explants. Plant Cell, Tissue and Organ Culture 69(1):79-83.

Kumar SP, Kumari BDR (2011). Factors affecting on somatic embryogenesis of safflower (Carthamus tinctorius $\mathrm{L}$ ) at morphological and biochemical levels. World Journal of Agricultural Sciences 7(2):197205.

Laplaze L, Benkova E, Casimiro I, Maes L, Vanneste S, Swarup R, ... Bennett $M$ (2007). Cytokinins act directly on lateral root founder cells to inhibit root initiation. The Plant Cell 19(12):3889-3900.

Lisowska K, Wysokinska H (2000). In vitro propagation of Catalpa ovata G. Don. Plant Cell, Tissue and Organ Culture 60:171-176.

Liszewska K (2011) Lactony jako związki biologicznie czynne. Biotechnology andFoodScience 75 (2):45-53. 
Mahesh A, Thangadurai D, Melchias G (2012). Rapid in vitro plant regeneration from leaf explants of Launaea sarmentosa (Willd.) Sch. Bip. ex Kuntze. Biological research 45(2):131-133.

Mallón R, Rodríguez-Oubiña J, González ML (2011). Shoot regeneration from in vitro-derived leaf and root explants of Centaurea ultreiae. Plant Cell, Tissue and Organ Culture 106(3):523-530.

MirekZ,Zarzycki K (2006). Red list of plants and fungi in Poland. IB PAN, Kraków.

Murashige T, Skoog F (1962). A revised medium for rapid growth and bioassays with tobacco tissue cultures. Physiologia Plantarum 15(3):437497.

Ozyigit II, Gozukirmizi N, Semiz BD (2007). Genotype dependent callus induction and shoot regeneration in sunflower (Helianthus annuus L.). African Journal of Biotechnology 6(13):1498-1502.

Perica MĆ, Vršek I, Mitić B (2008). In vitro propagation of Inula verbascifolia (Willd.) Hausskn. subsp. Verbascifolia. Plant Biosystems 142(1):1-4.

Rasool R, Ganai BA, Kamili AN, Akbar S, Masood A (2013). Synergistic effect of auxins and cytokinins on propagation of Artemisia amygdalina (Asteraceae), a critically endangered plant of Kashmir. Pakistan Journal of Botany 45(2):629-634.

Romano A (1997). Micropropagation of Dittrichia viscosa (L.) W. Greuter (sin. Inula viscosa (L.) Aiton). Acta Horticulturae 502.

Rutkowski L, Paszek I (2000). Inula germanica (Asteraceae) - potwierdzone stanowisko w rezerwacie "Bielinek" nad Odra [Inula germanica (Asteraceae) - confirmed locality in the "Bielinek" reserve on the Odra river (western Poland)]. Fragmenta Floristica et Geobotanica Polonica 7:372-375.

Rybczyński JJ, Mikuła A (2006). Engagement of biotechnology in the protection of threatened plant species in Poland. Biodiversity Research and Conservation 3-4:361-368.

Sharma A, Bhansali S, Kumar A (2013). In vitro callus induction and shoot regeneration in Eclipta alba (L.) Hassk. International Journal of Life Science and Pharma Research 3(2):43-46.

Shekhawat MS, Manokari M (2015). Efficient in vitro propagation by ex vitro rooting methods of Artemisia absinthium L, an ethnobotanically important plant. Chinese Journal of Biology 2015:1-8.

Stojakowska A, MalarzJ (2004). In vitro propagation of Inula royleana DC. ActaSocietatis Botanicorum Poloniae 73(1):5-8.

Surmacz-Magdziak A, Sugier D (2012). In vitro propagation of Arnica montana L.: an endangered herbal species of great importance to medicine. Acta Scientiarum Polonorum, Hortorum Cultus 11(2):127140.
Suthar RK, Habibi N, Purohit SD (2011). Influence of agar concentration and liquid medium on in vitro propagation of Boswellia serrata Roxb. Indian Journal of Biotechnology 10:224227.

Thiem B, Wesolowska M, Cis J (2003). In vitro culture of Inula verbascifolia ssp. aschersoniana and production of parthenolide. Herba Polonica 49(1-2):37-44.

Trejgell A, Chernetskyy M, Podlasiak J, Tretyn A (2013). Efficient regeneration system of Taraxacum pieninicum Pawt. from seedling explants. Acta Biologica Cracoviensia 55(1):73-79.

Trejgell A, Dąbrowska A, Tretyn A (2012). Micropropagation and influence of in vitro culture on development of regenerated plants of Cirsium pannonicum. ActaScientiarum Polonorum, Hortorum Cultus 11(5):81-90.

Trejgell A, Dąbrowska G, Tretyn A. (2009). In vitro regeneration of Carlina acaulis subsp. simplex from seedling explants. Acta Physiologiae Plantarum 31:445-453.

Trejgell A, Tretyn A (2010). Wydajność mikrorozmnażania w kulturach in vitro wybranych gatunków chronionych $\mathrm{z}$ rodziny Asteraceae [Micropropagation in in vitro culture efficiency of selected protected species Asteraceae]. Biotechnologia 90:202-209.

Trejgell A, Tretyn A (2011). Shoot multiplication and in vitro rooting of Carlina onopordifolia Basser. Acta Biologica Cracoviensia 53(2):68-72.

Tymoszuk A, Miler N, Zalewska M., Borawska M (2009). The rooting of chrysanthemum [Chrysanthemum $x$ Grandiflorum (RAMAT.) Kitam] in in vitro and in vivo conditions. Electronic Journal of Polish Agricultural 12:03.

Yucesan B, Turke AU, Gurel E (2007). TDZ-induced high frequency plant regeneration through multiple shoot formation in witloof chicory (Cichorium intybus L.). Plant Cell, Tissue and Organ Culture 91:243250.

Yüzbaşioğlu E, Dalyan E, Bona $\mathrm{M}, \mathrm{Öz} \mathrm{G}$ (2012). In vitro propagation of endemic plant Centaurea arifolia Boiss. Taxa. IUFS Journal of Biology 71(2):121-127.

Zobayed SMA, Saxena PK (2003). In vitro regeneration of Echinacea purpurea L.: Enhancement of somatic embryogenesis by indolebutyric acid and dark pre-incubation. In Vitro Cellular \& Developmental Biology-Plant 39(6):605-612. 